\title{
Hubungan Komunikasi Interpersonal dengan Kepuasan Pernikahan pada Suami Istri yang Berkarier
}

\author{
Rani Novita Wardani ${ }^{1}$, Yudi Suharsono ${ }^{2}$, Sofa Amalia ${ }^{3}$ \\ Fakultas Psikologi, Universitas Muhammadiyah Malang \\ e-mail: ${ }^{1}$ raninovita51@gmail.com, ${ }^{2}$ yudi@umm.ac.id, ${ }^{3}$ sofaamalia@umm.ac.id
}

\begin{abstract}
Marital satisfaction will be realized if there is good interpersonal communication between husband and wife. To realize good interpersonal communication, effective interpersonal communication skills are needed so that they can distance themselves from destructive situations that will cause dissatisfaction in marriage. This study aims to determine the relationship between interpersonal communication with the marital satisfaction of husband and wife who have a career with the type of correlational quantitative research. The subject of this study involved 124 people or 62 couples who both worked in Malang district using the snowball sampling technique. Data collection uses the marital satisfaction scale and interpersonal communication scale, then analyzed using Pearson product moment correlation using the SPSS application. Based on the results of the study, the value of the correlation ( $r$ ) on the husband was 0.791 with a probability of $0.000(p<0.05)$ while the correlation value $(r)$ for the wife was 0.700 with a probability of $0.000(p<0.05)$. This means that there is a positive and significant relationship between interpersonal communication and marital satisfaction on a career husband and wife.
\end{abstract}

KEYWORDS Career husband and wife, interpersonal communication, marriage satisfaction.

CITATION Wardani, R. N., Suharsono, Y., \& Amalia, S. (2019). Hubungan komunikasi interpersonal dengan kepuasan pernikahan pada suami istri yang berkarier. Cognicia, 7, (2), 241-257.

Masa dewasa adalah masa dimana kita akan membentuk sebuah keluarga baru melalui pernikahan. Pernikahan merupakan tahapan yang lebih serius baik bagi perempuan dan laki-laki untuk mengikat janji dimana akan menjalani kehidupan secara bersama-sama sebagai suami istri. Sehingga dua individu dari keluarga berbeda, latar belakang yang berbeda dan kepribadian yang berbeda menjadi satu, hidup bersama-sama untuk mendirikan sebuah keluarga baru (Paputungan, 2012). Peran dalam keluarga akan terbagi sesuai dengan posisinya. Suami sebagai tulang punggung keluarga mencari nafkah untuk memenuhi kebutuhan sehari-hari, sedangkan istri mengurus rumah tangga dan mempersiapkan kebutuhan suami dan anak (Puspitawati, 2012).

Sedangkan sekarang suami dan istri sama-sama berkarier untuk memperkuat prekonomian keluarga, aktualisasi diri, serta adanya kemajuan teknologi, pendidikan dan informatika sehingga membuka kesempatan yang luas tidak hanya kepada lelaki tetapi juga perempuan (Suryani dalam Taneira, 2019; Manalu, Rosyadi, \& Saidin, 2014). 
Hal ini ditunjukkan adanya peningkatan angkatan kerja pada perempuan. Berdasarkan data Badan Pusat Statistik pada bulan Februari 2017, jumlah pekerja lakilaki sebesar $83,05 \%$ atau turun $0,41 \%$ dibandingkan periode sebelumnya yaitu $83,46 \%$. Jumlah pekerja perempuan sebesar 55,04\% hal ini menunjukkan adanya peningkatan dibandingkan periode sebelumnya yaitu sebesar 52,71\% (Ali, 2017). Data tersebut menunjukkan adanya peningkatan jumlah cenderung pada perempuan dibandingkan laki-laki.

Pada umumnya terdapat 2 model keluarga, yaitu tradisional dan modern (Puspitawati, 2012). Pada model keluarga tradisional pembagian tugas sangatlah jelas. Istri sebagai ibu rumah tangga, tidak ada istri yang bekerja di luar rumah, dan suami bekerja di luar. Sedangkan model keluarga modern peran mereka fleksibel, suami bekerja di luar namun mulai membantu tugas istri, dan istri mengurus rumah tangga dan mambantu bekerja di luar. Dari kedua model keluarga tersebut peneliti lebih menitik beratkan pada model keluarga modern dikarenakan keluarga ini menghadapi terlalu banyak masalah karena perlu memainkan terlalu banyak peran dan terlalu banyak tuntutan pada waktu dan energi (Lee dalam Sultana, Ayesha, \& Abu, 2014).

Ada berbagai persoalan yang dihadapi oleh pasangan suami istri berkarier adalah kepercayaan, yang memiliki hubungan signifikan dengan tingkat kepuasan pernikahan (Atta et. al., 2013). Pada kondisi pernikahan dimana istri memilih untuk berkarier, kepuasan pernikahan yang didapat rendah jika kepercayaan suami juga rendah. Hal ini bisa disebabkan karena istri mereka mempunyai rekan yang tidak hanya perempuan saja tetapi juga lawan jenis. Selain itu kepuasan pernikahan yang rendah juga dapat menyebabkan ketegangan psikologis, kepuasan kerja dan keluarga berkurang (Kalliath, Thomas, \& Varsha, 2011). Dampak lain yang muncul adalah pengaruhnya terhadap tingkat kepuasan keintiman fisik karena istri berkarier fulltime (Paputungan, 2012). Masalah-masalah yang dipaparkan sebelumnya tersebut akan menjadi semakin kompleks ketika terdapat kehadiran anak dalam pasangan suami istri berkarier karena peran dan tanggung jawab pengasuhan anak berpengaruh negatif terhadap kualitas dan kepuasan pernikahan (Thomas, Kay, \& Priscilla, 1984). Dapat disimpulkan ternyata pada pasangan suami istri yang berkarier sangat banyak permasalahan yang dihadapi hal ini jika tidak segera diselesaikan dapat mengakibatkan ketidakpuasan pernikahan dan akan berujung pada percerian.

Menjalani sebuah pernikahan tidak selalu mengalami kebahagian saja tetapi juga adanya permasalahan yang timbul karena berbagai alasan. Saat pasangan bisa menyelesaikan permasalahan yang ada maka akan semakin kuatlah pernikahan mereka, tetapi ketika pasangan tersebut tidak bisa menyelesaikan semua permasalahan dan hanya dibiarkan saja maka semakin lama akan mengakibatkan perceraian. Data perceraian pasangan suami istri yang berkarier di Kabupaten Malang sendiri mengalami peningkatan. Dalam laman radarmalang.id (2018) terdapat angka perceraian sebesar 2.898 perkara pada tahun 2017 dan meningkat menjadi 3.186 perkara di tahun 2018 sehingga adanya peningkatan sebesar 9 persen. Pada kabupaten Malang, kasus cerai gugat lebih besar daripada cerai talak, yang berarti istri menggugat cerai kepada suami sebesar 2.159 dari 3.186 perkara. Penyebab perceraian di Kabupaten Malang sendiri dikarenakan kurangnya komunikasi antara pasangan suami istri dan faktor lain yaitu ekonomi. 
Kepuasan pernikahan merupakan elemen kunci dari kebahagiaan yang dirasakan pasangan. Pasangan yang menginginkan keharmonisan dan kebahagiaan dalam pernikahan mereka disebut dengan kepuasan dalam pernikahan. Kepuasan pernikahan adalah penilaian secara umum pada kondisi pernikahan yang sedang dihadapi setiap pasangan (Brockwood, 2007). Penilaian secara umum ini berupa seberapa bahagianya pasangan suami istri menjalani kehidupan pernikahannya, penyelesaian permasalahan dalam lingkup pernikahan atau gabungan dalam aspekaspek dalam kepuasan pernikahan itu sendiri. Brandbury, Frank, \& Steven (2000) menyatakan ada 6 aspek yaitu: kognitif, afeksi, fisiologis, pola interaksi, dukungan sosial, dan kekerasan. Pada penelitian Meliani, Euis, \& Dian (2014) didapatkan hasil bahwa adanya persentase tertinggi kedua pada istri berkarier untuk mencapai kepuasan pernikahan yaitu komunikasi sebesar 77,5\%. Dari penelitian ini istri merasa pasangannya memahami dan simpati kepadanya dan merasa bahagia dengan cara komunikasi dengan pasangannya.

Permasalahan-permasalahan tersebut tidak akan ada atau akan bisa diselesaikan jika komunikasi antar pasangan baik karena setiap keluarga memerlukan komunikasi untuk menyatukan setiap individu karena masing-masing memiliki tujuan yang berbeda (Maskud, 2015). Hal ini didukung dengan penelitian Askari et. al., (2012) meneliti pada pasangan Iran untuk menguji pengaruh pelatihan komunikasi dan pelatihan resolusi konflik terhadap kepuasan pernikahan. Hasil menunjukkan pelatihan komunikasi dan resolusi konflik efektif dalam meningkatkan kepuasan pernikahan. Gabungan antara keduanya menghasilkan mental dan kesehatan pasangan yang lebih baik dan membantu pasangan untuk mengatasi konflik pernikahan. komunikasi yang digunakan pada pasangan ini dengan mendiskusikan ide, pengalaman, permasalahan satu sama lain. Sesuai dengan penelitian Ochsner (2012) pada penelitian kualitatif menunjukkan bahwa pasangan yang mampu mempertahankan komunikasi terbuka, berdiskusi mengenai tekanan dan konflik pada pernikahan, membuat jadwal untuk kumpul dan membagi tugas, dan memberikan waktu bersama dengan pasangan membuat pernikahan mereka paling memuaskan.

Kemudian menurut Donan dan Jhonson (dalam Sari, \& Nailul, 2016). Pasangan yang memiliki komunikasi yang baik akan bisa menyelesaikan dan bisa mengatasi konflik yang dialami pada pasangan suami istri berkarier. Kesadaran setiap pasangan dalam berkomunikasi adalah salah satu faktor untuk menjaga suatu hubungan tetap bertahan dan puas akan kehidupan pernikahannya. Bisa dilihat dari penelitian Carroll at. al., (2012) yang berjudul Couple Communication as a Mediator Between Work-Family Conflict and Marital Satisfaction menemukan hasil bahwa konflik kerja keluarga secara signifikan dan negatif terhadap kepuasan pernikahan. Hubungan ini tidak menjadi signifikan ketika komunikasi konstruktif ditambahkan dalam variabel sebagai mediator. Sedangkan Komunikasi destruktif yang bersifat kritik, penghinaan, sikap membela diri mengirim pernikahan ke arah perceraian dan komunikasi destruktif ini dapat memperburuk efek dari konflik kerja keluarga. Hal ini sependapat dengan Holman (2001) menemukan kualitas komunikasi pasangan adalah prediktor terbaik dari kepuasan pernikahan dan penelitian ini juga menunjukkan bahwa pasangan yang memiliki komunikasi berkualitas tinggi bisa menjadi penyangga terhadap faktor-faktor yang akan menyebabkan kepuasan pernikahan yang lebih rendah. 
Komunikasi merupakan indikator kunci yang menunjukkan kualitas dan stabilitas hubungan suami istri. Komunikasi yang sering digunakan suami istri dalam berinteraksi adalah komunikasi interpersonal. Komunikasi interpersonal merupakan komunikasi antara orang-orang secara tatap muka, yang memungkinkan setiap individu menangkap reaksi orang lain secara langsung, baik secara verbal maupun non-verbal. Hal tersebut didukung dengan hasil penelitian yang dilakukan oleh Rahma (2016) yang menjelaskan bahwa suami yang mempunyai istri berkarier merasa bahwa kurang puas dalam pernikahannya dikarekanakan istri jarang di rumah hal ini mengakibatkan kepuasan fisik berkurang. Selain itu suami menjelaskan pernikahan mereka puas jika pasangan mampu membuat suasana terbuka dengan cara berkomunikasi, dengan adanya komunikasi akan bisa memahami satu sama lain sehingga mampu untuk memenuhi kepuasan fisik yang kurang tersebut.

Penelitian lain juga menyebutkan bahwa komunikasi antar pasangan adalah elemen utama untuk hubungan pernikahan yang bahagia dan sehat ditunjukkan dengan hasil adanya korelasi yang signifikan antara komunikasi dan kepuasan pernikahan. Penelitian ini juga menjelaskan komunikasi yang efektif antar pasangan ketika bersedia untuk membuka diri secara bebas dan jujur, yang siap untuk mendengarkan satu sama lain secara aktif dan mengakomodasi perbedaan dengan sabar sehingga hubungan pernikahan lebih memuaskan (Vazhappilly, \& Marc, 2016). Selain itu hasil dari penelitian Hou, Feng, dan Xinrui (2018) menjelaskan komunikasi mempengaruhi hubungan komitmen pernikahan dan kepuasan pernikahan secara signifikan. Dijelaskan juga istri menunjukkan kualitas komunikasi yang lebih tinggi yang memperkuat hubungan antara komitmen dan kepuasan pernikahan mereka dari pada suami. Sedangkan dari penelitian dari Lavner, Benjamin, dan Thomas (2016) didapatkan hasil adanya hubungan signifikan pada komunikasi dan kepuasan pernikahan. Menjelaskan pasangan yang lebih puas dalam pernikahannya menunjukkan komunikasi antar pasangan lebih positif, kurang negatif dan lebih efektif.

Karier merupakan kehidupan kerja individu dimana setiap tahapan karier akan mengalami peningkatan seiring dengan pengalaman kerja individu tersebut (Corey, 2005). Sehingga peneliti tertarik untuk meneliti hubungan komunikasi interpersonal dengan kepuasan pernikahan pada suami istri yang berkarier. Selain itu kebanyakan subjek yang digunakan ialah pasangan yang baru menikah, terdapat juga penelitian lain yang menggunakan juga suami istri berkarier namun hanya saja melihat di satu pihak yaitu suami atau istri.

Rumusan masalah yang akan diangkat dalam penelitian ini adalah "apakah ada hubungan komunikasi interpersonal dengan kepuasan pernikahan pada suami berkarier" dan "apakah ada hubungan komunikasi interpersonal dengan kepuasan pernikahan pada istri berkarier". Adapun tujuan dari penelitian ini adalah untuk mengetahui hubungan komunikasi interpersonal dengan kepuasan pernikahan pada suami berkarier dan untuk mengetahui hubungan komunikasi interpersonal dengan kepuasan pernikahan pada istri berkarier, sehingga permasalahan pada suami istri yang berkarier bisa berkurang atau bisa teratasi dengan menganalisa hubungan dua variabel tersebut. Manfaat penelitian secara teoritis ialah memberikan sumbangan pada ilmu psikologi perkembangan dan psikologi sosial. Sedangkan secara praktis memberikan informasi pada pasangan yang akan menikah atau yang sudah menikah 
khususnya pada suami istri berkarier. Diharapkan dari penelitian ini dapat tercapainya kepuasan pernikahan melalui komunikasi interpersonal sehingga dapat mempertahankan pernikahannya.

\section{METODE}

Penelitian ini mengunakan pendekatan kuantitatif dengan desain korelasional. Menurut Azwar (2013) pendekatan kuantitatif menekankan analisis berupa data-data angka yang diolah dengan metode statistika dalam rangka pengujian hipotesis. Sedangkan korelasional dimaksudkan untuk mengetahui ada tidaknya hubungan variabel terikat terhadap varibel bebas (Arikunto, 2010).

Subjek yang akan digunakan dalam penelitian ini adalah pasangan suami istri yang berkarir yang berdomisi di Kabupaten Malang. Pengambilan sampel subjek dalam penelitian ini menggunakan teknik snowball sampling dimana pengambilan sampel bermula-mula jumlahnya sedikit kemudian sampel ini disuruh memilih kerabat-kerabatnya untuk dijadikan sampel selanjutnya ibarat sebuah bola salju yang menggelinding, makin lama semakin besar (Sugiono, 2014).

Adapun kriteria subjek yaitu:

1. Pasangan suami istri

2. Istri dan suami memiliki pekerjaan full time dengan jam kerja minimal 8 jam per hari.

3. Memiliki anak minimal satu

4. Tinggal bersama dalam satu rumah

5. Berdomisili di Kabupaten Malang

Pada penelitian ini, terdapat dua variabel yaitu varibel terikat (Y) adalah kepuasan pernikahan dan variabel bebas (X) yaitu komunikasi interpersonal. Kepuasan pernikahan adalah perasaan suami atau istri dalam menjalani pernikahan atas perasaan yang bahagia secara bersama-sama dengan meliputi aspek-aspek seperti kognitif, pola interaksi, afeksi, dukungan sosial, fisiologis dan kekerasan. Instrumen yang digunakan adalah skala kepuasan pernikahan yang diadaptasi dari penelitian Nurmaya (2016) yang mengacu pada teori Bradbury (2000) sebanyak 36 item. Setelah dilakukannya uji validitas dan reliabilitas diperoleh hasil item valid terdapat 18 item dengan indeks validitas 0,373-0,689 dan indeks reliabilitas sebesar 0,905.

Komunikasi Interpersonal adalah penilaian suami atau istri yang berkaitan dengan komunikasi yang dilakukan antara dirinya dengan pasangan yang mencakup aspek-aspek komunikasi interpersonal yaitu empati, kesetaraan, keterbukaan, sikap positif, dan sikap mendukung. Instrumen yang digunakan adalah skala komunikasi interpersonal yang disusun oleh peneliti mengacu pada teori Devito (1997) sebanyak 40 item. Setelah dilakukannya uji validitas dan reliabilitas diperoleh hasil item valid terdapat 14 item dengan indeks validitas $0,362-0,662$ dan indeks reliabilitas sebesar 0,873 .

Pada penelitian ini kedua alat ukur menggunakan skala likert yang disusun dengan item pendukung (favorable) dan item tidak mendukung yaitu (unfavorable). Dalam setiap item pernyataan mempunyai empat pilihan jawaban yaitu Sangat Sesuai (SS), Sesuai (S), Tidak Sesuai (TS), dan Sangat Tidak Sesuai (STS). Pada item favorable 
akan diberikan skor 4 untuk sangat setuju, skor 3 untuk setuju, skor 2 untuk tidak setuju, dan skor 1 untuk sangat tidak setuju. Sedangkan pada item unfavorable diberikan skor 1 untuk sangat setuju, skor 2 untuk setuju, skor 3 untuk tidak setuju, dan skor 4 untuk sangat tidak setuju.

Tahap persiapan yaitu mencari atau mengumpulkan data-data terkait fenomena dan mencari teori yang berhubungan dengan variabel yang diteliti sehingga memperdalam penelitian yang diteliti, serta mencari instrumen kepuasan pernikahan dan membuat instrumen komunikasi interpersonal. Sebelum penelitian, instrumen diuji coba dimulai tanggal 29 Maret - 12 April 2019 pada 42 orang atau 21 sepasang suami istri dengan kriteria suami dan istri sama-sama bekerja di instansi tertentu dengan memiliki jam kerja minimal 8 jam perhari, memiliki anak setidaknya 1, suami dan istri tinggal dalam satu rumah, dan tinggal di kota Malang. Setelah selesai diuji coba peneliti melakukan analisa data menggunakan Statistical Package For Social Sciense (SPSS) 21 untuk mendapatkan item yang valid dan reliabel.

Selanjutnya pada tahap pengambilan data, peneliti menyebarkan skala yang berisi 2 instrumen yaitu komunikasi interpersonal dan kepuasan pernikahan dilakukan mulai tanggal 5 Mei - 21 pada 124 orang atau 62 sepasang suami istri yang sesuai dengan kriteria yang sudah ditentukan dengan menggunakan teknik snowball sampling.

Terakhir tahap analisis dimana data yang didapatkan semua selanjutnya di entry sesuai skor skala likert kemudian diolah menggunakan Statistical Package For Social Sciense (SPSS) 21 yaitu dengan menggunakan metode analisa Correlation Person Product Moment.

\section{HASIL}

Penelitian ini melibatkan subjek sebanyak 124 orang atau 62 sepasang suami istri dengan kriteria yang sudah ditentukan yaitu pasangan suami dan istri yang samasama bekerja di intansi tertentu dengan jam kerja minimal 8 jam perhari, dengan jumlah anak minimal 1, tinggal bersama dalam satu rumah, dan tinggal di Kabupaten Malang. Berikut ini data demografi suami dan istri.

Tabel 1. Deskripsi Subjek Penelitian

\begin{tabular}{|c|c|c|c|}
\hline \multirow{2}{*}{ Kategori } & \multicolumn{2}{|c|}{ Frekuensi } & \multirow{2}{*}{ Persentase } \\
\hline & Suami & Istri & \\
\hline \multicolumn{4}{|l|}{ Usia } \\
\hline 20-25 tahun & 10 & 19 & $23,4 \%$ \\
\hline 26-30 tahun & 17 & 19 & $29 \%$ \\
\hline 31-35 tahun & 17 & 9 & $21 \%$ \\
\hline 36-40 tahun & 9 & 9 & $14,5 \%$ \\
\hline 41-45 tahun & 9 & 6 & $12,1 \%$ \\
\hline \multicolumn{4}{|l|}{ Pekerjaan } \\
\hline Pegawai swasta & 43 & 50 & $75 \%$ \\
\hline PNS & 19 & 10 & $25 \%$ \\
\hline \multicolumn{4}{|l|}{ Jumlah Anak } \\
\hline 1 anak & \multicolumn{2}{|c|}{29} & $47 \%$ \\
\hline 2 anak & \multicolumn{2}{|c|}{21} & $34 \%$ \\
\hline
\end{tabular}


$>2$

Pendidikan Terakhir

\begin{tabular}{cccc} 
D3 & 7 & 6 & $10,5 \%$ \\
D4/S1 & 43 & 48 & $73,4 \%$ \\
S2 & 10 & 8 & $14,5 \%$ \\
S3 & 2 & 0 & $1,6 \%$ \\
\hline Total & $\mathbf{6 2}$ & $\mathbf{6 2}$ & $\mathbf{1 0 0} \%$ \\
\hline
\end{tabular}

Berdasarkan tabel di atas diketahui sebaran subjek dari kategori usia 20-40 tahun merupakan fase dewasa awal sedangkan usia 41-45 tahun pada fase dewasa menengah. Dari kedua fase tersebut subjek terbanyak pada penelitian ini adalah fase dewasa awal dengan total keseluruhan 109 sedangkan fase dewasa menengah sebesar 15 orang. Untuk dewasa awal sendiri usia terbanyak subjek dengan rentan usia 26-30 tahun dengan persentase 29\%, dilanjutkan usia 20-25 tahun dengan persentase 23,4\%, kemudian 31-35 tahun sebesar 21\%, dan terakhir 36-40 tahun sebesar 14,5\%. Sedangkan fase dewasa menengah dengan usia 41-45 tahun mendapatkan hasil sebesar 12,1\%.

Selain data usia diketahui pekerjaan subjek yaitu pegawai swasta dan PNS, dari kedua jenis pekerjaan tersebut subjek terbanyak bekerja sebagai pegawai swasta dengan persentase $75 \%$, diikuti dengan PNS sebesar 25\%. Sedangkan berdasarkan jumlah anak subjek terbanyak mempunyai anak 1 sebesar $47 \%$, dilanjutkan 2 anak sebesar 34\%, dan 3 anak dengan persentase 18\%. Selain itu dari latar belakang sebaran subjek berada pada pendidikan D3 hingga S3. Sebagian besar berpendidikan D4/S1 yaitu $73,4 \%$, sedangkan yang paling sedikit berpendidikan S3 dengan persentase $1,6 \%$.

Tabel 2. Uji Homogenitas \& Uji Linearitas

Mengingat bahwa di dalam penelitian ini dilakukan uji beda, Maka terlebih dahulu dilakukan uji homogenitas dan uji linearitas.

\begin{tabular}{cccc}
\hline Uji Homogenitas & Sig & Uji Linearitas & $\begin{array}{c}\text { Sig Deviation from } \\
\text { Linearity }\end{array}$ \\
\hline $\begin{array}{c}\text { Komunikasi } \\
\text { Interpersonal Suami Istri }\end{array}$ & 0,593 & $\begin{array}{l}\text { Kepuasan pernikahan dan } \\
\text { komunikasi interpersonal } \\
\text { pada suami }\end{array}$ & 0,357 \\
$\begin{array}{c}\text { Kepuasan Pernikahan } \\
\text { Suami Istri }\end{array}$ & 0,372 & $\begin{array}{c}\text { Kepuasan pernikahan dan } \\
\text { komunikasi interpersonal } \\
\text { pada istri }\end{array}$ & 0,155 \\
\hline
\end{tabular}

Berdasarkan uji homogenitas menunjukkan nilai signifikan komunikasi interpersonal suami istri sebesar 0,593 kemudian kepuasan pernikahan suami istri sebesar 0,372. Data dari kedua variabel tersebut dikatakan homogen karena nilai signifikan $>0,05$. Dilanjutkan dengan uji linearitas dikatakan linier apabila nilai sig deviation from linearity lebih besar dari 0,05. Berdasarkan uji linearitas diketahui nilai sig deviation from linearity pada suami sebesar 0,357 sedangkan pada istri sebesar 0,155 yang berarti kedua variabel pada suami dan istri memiliki hubungan yang linier. Setelah melakukan uji homogenitas dan uji linearitas, didapatkan hasil berupa data 
termasuk dalam kategori homogen dan linier maka bisa dilanjutkan untuk masuk uji normalitas.

Tabel 3. Uji Normalitas

Sebelum menguji korelasi terlebih dahulu dilakukan pengujian menggunakan uji normalitas melalui uji Kolmogorov-Smirnov.

\begin{tabular}{ccc}
\hline & Komunikasi Interpersonal & Kepuasan Pernikahan \\
\hline Suami & 0,437 & 0,145 \\
Istri & 0,609 & 0,470 \\
\hline
\end{tabular}

Hasil uji normalitas data suami didapatkan hasil sig (2-tailed) sebesar 0,437 pada variabel komunikasi interpersonal dan 0,145 pada variabel kepuasan pernikahan. Sedangkan pada data istri didapatkan nilai sig (2-tailed) sebesar 0,609 pada variabel komunikasi interpersonal dan pada variabel kepuasan pernikahan sebesar 0,470. Syarat data dikatakan normal apabila nilai sig (2-tailed) $>0,05$. Sehingga dapat disimpulkan bahwa setiap variabel pada suami maupun istri dikatakan normal.

Dari uji homogenitas, linearitas, dan normalitas ternyata seluruh uji yang menjadi persyaratan untuk pengujian beda dan korelasi memenuhi syarat karena itu menunjukkan semua data homogen, kedua variabel memiliki hubungan linier, dan normal. Sehingga bisa dilanjutkan dengan uji berikutnya.

Tabel 4. Uji Beda

\begin{tabular}{cc}
\hline Uji Beda & Sig (2-tailed) \\
\hline Komunikasi Interpersonal suami Istri & 0,289 \\
Kepuasan pernikahan suami istri & 0,384 \\
\hline
\end{tabular}

Dari tabel 5 dapat kita simpulkan bahwa tidak terdapat perbedaan yang signifikan antara komunikasi interpersonal maupun kepuasan pernikahan pada suami dan istri. Hal ini dikarekan nilai sig (2-tailed) lebih besar dari 0,05.

Tabel 5. Uji Korelasi

\begin{tabular}{lccc}
\hline & $\begin{array}{c}\text { Koefisien Korelasi } \\
(\mathbf{r})\end{array}$ & Koefisien Determinasi $\left(\mathbf{r}^{2}\right)$ & Sig (2-tailed) \\
\hline Suami & 0,791 & 0,625 & 0,000 \\
Istri & 0,700 & 0,490 & 0,000 \\
\hline
\end{tabular}

Pada suami dapat diketahui bahwa nilai signifikan $0.000<0,05$ maka berkorelasi, selain itu untuk nilai koefisien korelasi (r) sebesar 0,791 dikatakan korelasi yang kuat dan positif ditunjukkan dengan tidak ada tanda (-) pada nilai koefisien korelasi. Adapun pada istri dapat diketahui bahwa nilai signifikan $0.000<0,05$ maka berkorelasi, selain itu untuk nilai koefisien korelasi (r) sebesar 0,700 yang berarti korelasi kuat yang positif ditunjukkan dengan tidak ada tanda (-) pada nilai koefisien korelasi. Sehingga dapat disimpulkan bahwa terdapat hubungan signifikan yang kuat pada komunikasi interpersonal dengan kepuasan pernikahan suami maupun istri. Sumbangan efektif 
pada komunikasi interpersonal terhadap kepuasan pernikahan pada suami ternyata berkontribusi sebesar $62,5 \%$, sedangkan istri sebesar $49 \%$ sisanya dipengaruhi oleh faktor lain.

Tabel 6. Kategori Tingkat Komunikasi Interpersonal dan Kepuasan Pernikahan

\begin{tabular}{lcccc}
\hline & \multicolumn{2}{c}{ Komunikasi Interpersonal } \\
Efektif & Tidak Efektif \\
T-score $>\mathbf{5 0}$ & T-score $<\mathbf{5 0}$ & Kepuasan Pernikahan \\
& & & $\begin{array}{c}\text { Puas } \\
\text { T-score }>\mathbf{5 0}\end{array}$ & $\begin{array}{c}\text { Tidak Puas } \\
\text { T-score }<\mathbf{5 0}\end{array}$ \\
\hline Istri & $32(52 \%)$ & $30(48 \%)$ & $36(58 \%)$ & $26(42 \%)$ \\
Suami & $37(60 \%)$ & $25(40 \%)$ & $32(52 \%)$ & $30(48 \%)$ \\
\hline
\end{tabular}

Sebagian besar suami dan istri menyatakan bahwa mereka merasa memiliki kepuasan dalam pernikahan. Demikian halnya dengan komunikasi, pasangan suami istri sebagian besar memiliki komunikasi yang efektif dari pada yang tidak efektif. Dengan tetap tidak mengesampingkan fakta bahwa ada sebagian diantaranya merasa tidak puas terkait pernikahannya.

Tabel 7. Kategori Tingkat Komunikasi Interpersonal dan Kepuasan Pernikahan Berdasarkan Pendidikan

\begin{tabular}{ccccc}
\hline & \multicolumn{2}{c}{ Komunikasi Interpersonal } & \multicolumn{2}{c}{ Kepuasan Pernikahan } \\
\hline Suami & $\begin{array}{c}\text { Efektif } \\
\text { T-score }>\mathbf{5 0}\end{array}$ & $\begin{array}{c}\text { Tidak } \\
\text { Efektif } \\
\text { T-score }<50\end{array}$ & $\begin{array}{c}\text { Puas } \\
\text { T-score }>50\end{array}$ & $\begin{array}{c}\text { Tidak Puas } \\
\text { T-score }<50\end{array}$ \\
\hline D3 & $2(3,2 \%)$ & $5(8,1 \%)$ & $3(4,8 \%)$ & $4(6,5 \%)$ \\
D4/S1 & $24(38,7 \%)$ & $19(30,6 \%)$ & $24(38,7 \%)$ & $19(30,6 \%)$ \\
S2 & $5(8,1 \%)$ & $5(8,1 \%)$ & $9(14,5 \%)$ & $1(1,6 \%)$ \\
S3 & $1(1,6 \%)$ & $1(1,6 \%)$ & $1(1,6 \%)$ & $1(1,6 \%)$ \\
\hline & Efektif & Tidak & Puas & Tidak Puas \\
Istri & T-score $>\mathbf{5 0}$ & Efektif & T-score $>50$ & T-score $<50$ \\
& $3,2 \%$ & $6,5 \%$ & $4 \%$ & $4,8 \%$ \\
D3 & $45,2 \%$ & $32,3 \%$ & $41,9 \%$ & $35,5 \%$ \\
D4/S1 & $9,7 \%$ & $3,2 \%$ & $4,8 \%$ & $8,1 \%$ \\
S2 & & & &
\end{tabular}

Berdasarkan tabel 7 menunjukkan persentase suami maupun istri yang memiliki komunikasi interpersonal tertinggi berada pada tingkat pendidikan D4/S1 sebesar $38,7 \%$ suami dan $45,2 \%$ pada istri. Sedangkan persentase suami dan istri yang memiliki tingkat kepuasan pernikahan yang tertinggi berada pada tingkat pendidikan D4/S1 sebesar $38,7 \%$ pada suami dan $41,9 \%$ pada istri. Dapat disimpulkan suami maupun istri dengan tingkat komunikasi interpersonal dan kepuasan pernikahan tertinggi berada pada latar pendidikan D4/S1. 
Tabel 8. Kategori Tingkat Komunikasi Interpersonal dan Kepuasan Pernikahan Berdasarkan Jumlah Anak

\begin{tabular}{ccccc}
\hline \multirow{2}{*}{$\begin{array}{c}\text { Kumlah } \\
\text { Komunikasi Interpersonal }\end{array}$} & \multicolumn{2}{c}{ Kepuasan Pernikahan } \\
Efektif & Tidak Efektif & Puas & Tidak Puas \\
& T-score $>\mathbf{5 0}$ & T-score $<50$ & T-score $>\mathbf{5 0}$ & T-score $<50$ \\
\hline 1 & $18(29, \mathbf{1} \%)$ & $11(17,7 \%)$ & $20(32,2 \%)$ & $9(14,5 \%)$ \\
2 & $10(16,1 \%)$ & $11(17,7 \%)$ & $13(21 \%)$ & $8(12,9 \%)$ \\
$>2$ & $5(8,1 \%)$ & $7(11,3 \%)$ & $5(8,1)$ & $7(11,3 \%)$ \\
\hline Jumlah & Efektif & Tidak Efektif & Puas & Tidak Puas \\
anak Istri & T-score $>\mathbf{5 0}$ & T-score $<50$ & T-score $>50$ & T-score $<50$ \\
\hline 1 & $16(25,8 \%)$ & $13(21 \%)$ & $15(24,2 \%)$ & $14(22,6 \%)$ \\
2 & $13(21 \%)$ & $8(12,9 \%)$ & $12(19,4 \%)$ & $9(14,5 \%)$ \\
$>2$ & $7(11,3 \%)$ & $5(8,1 \%)$ & $5(8,1 \%)$ & $17(1,3 \%)$ \\
\hline
\end{tabular}

Secara umum, pasangan yang memiliki satu anak sebagian suami istri menyatakan komunikasi interpersonal mereka efektif, dan juga diikuti dengan kepuasan pernikahan. Sebaliknya jumlah anak yang semakin banyak menunjukkan tingkat komunikasi interpersonal pasangan yang tidak efektif karena suami ataupun istri terlalu banyak berinteraksi kepada anaknya sehingga, pasangan tidak mendapatkan bagian berinteraksi jika dibandingkan dengan kondisi pasangan yang belum mempunyai anak atau yang hanya memiliki satu anak.

\section{DISKUSI}

Dari analisa data yang telah dilakukan pada suami yang berkarier menunjukkan nilai korelasi sebesar 0,791 yang artinya korelasi kuat dengan $P=0,000$ sehingga dapat diterima. Hasil menunjukkan terdapat korelasi positif, yang artinya semakin efektif komunikasi interpersonal maka semakin tinggi pula tingkat kepuasan pernikahan pada suami berkarier dan sebaliknya, semakin tidak efektif komunikasi interpersonal maka semakin rendah pula tingkat kepuasan pernikahan pada suami berkarier Sedangkan bagaimana hubungan antara komunikasi interpersonal dengan kepuasan pernikahan pada istri yang berkarier. Hasil menunjukkan nilai korelasi pada istri sebesar 0,700 yang artinya korelasi kuat dengan $\mathrm{P}=0,000$ sehingga dapat diterima. Terdapat korelasi positif yang artinya semakin efektif komunikasi interpersonal maka semakin tinggi pula kepuasan pernikahan pada istri berkarier dan sebaliknya, semakin tidak efektif komunikasi interpersonal maka semakin rendah pula tingkat kepuasan pernikahan pada istri berkarier. Dapat ditarik kesimpulan bahwa ada hubungan positif dan signifikan yang kuat antara komunikasi interpersonal dengan kepuasan pernikahan pada suami maupun istri berkarier. Sehingga dengan memiliki kemampuan komunikasi interpersonal yang efektif pada suami dan istri dapat mampu menyampaikan pikiran, pendapat, perasaan, informasi serta dapat menyelesaikan masalah baik itu pekerjaan maupun keluarga sehingga membuat pasangan menjadi saling memahami satu sama lain, dapat menyelesaikan permasalahan secara bersamasama, saling bekerja sama dalam hal pekerjaan maupun urusan rumah tangga, serta 
menerima kelebihan dan kekurangan pada pasangan mereka sehingga hal tersebut menimbulkan kepuasan pernikahan kedua belah pihak.

Hal ini diperkuat dengan hasil penelitian Dahuji, Tavakkoli, dan Neamatolahi (dalam Muslimah, 2014) menjelaskan seseorang yang memiliki komunikasi interpersonal yang baik pada pasangan mereka memiliki kepuasan pernikahan yang lebih tinggi daripada seseorang yang kurang mampu berkomunikasi pada pasangannya. Kemampuan dalam hal mengungkapkan pemikiran, gagasan ataupun ide sangat menentukan kedekatan pada pasangan, ketika semakin baik seseorang dalam hal mengungkapkan berarti semakin baik pula dalam hal hubungan pada pasangan Olson (dalam Muslimah, 2014). Untuk pasangan suami istri yang kurang mampu dalam berkomunikasi akan mengalami kurangnya empati pada pasangan dan munculnya krisis kepercayaan (Lavner, Karney \& Brandbury, 2013). Kurangnya hal tersebut akan membuat di dalam pernikahan mereka tidak berjalan harmonis dan tentu cenderung akan membuat bosan dikarenakan ekspresi terhadap perasaan tidak dapat muncul dan pasangan tidak mendapatkan kebutuhan afeksi yang mereka butuhkan (Muslimah, 2014).

Hasil analisis data dikemukakan bahwa tidak ada perbedaan signifikan komunikasi interpersonal dengan kepuasan pernikahan pada suami dan istri. Sehingga keduanya baik suami maupun istri tidak terdapat perbedaan dalam hal berkomunikasi meskipun mereka mempunyai tuntutan dalam bekerja maka kepuasan pernikahan tetap bisa diperoleh. Sependapat dengan penelitian Ayub (2010) menjelaskan komunikasi merupakan sarana utama dalam pernikahan yang digunakan oleh pasangan untuk saling berhubungan dan mengelola dalam proses sosial, dan kognitif yang mendasari komunikasi berperan penting dalam kemampuan untuk beradaptasi dalam hal kepuasan pernikahan dan perkembangan relasional yang sedang berlangsung.

Kita mengetahui bahwa suami dan istri yang sama-sama bekerja menuntut mereka dalam hal pekerjaan maupun dalam urusan rumah tangga. Masalah yang sering mendasar dalam keluarga modern ialah adanya keterbatasan waktu untuk meluangkan waktu mereka dalam hal hubungan terhadap pasangan maupun keluarga baik itu melakukan kewajiban yang semestinya dikerjakan istri seperti mencuci baju, membersihkan rumah maupun urusan mengurusi anak. Untuk itu peran laki-laki atau suami sangat diperlukan dalam membagikan peran mereka. Berdasarkan hasil t-score tinggi dan rendah pada komunikasi interpersonal suami memperoleh nilai $60 \%$ dan istri 52\% dengan kategori tinggi sedangkan pada kepuasan pernikahan dengan kategori tinggi 52\% untuk suami dan istri 58\%. Berdasarkan t-score memperoleh sebagian besar suami dan istri memiliki komunikasi yang tinggi sehingga di dalam suami istri yang sama-sama bekerja mereka mampu dalam hal berkomunikasi meskipun adanya keterbatasan waktu sehingga mereka mampu mengkomunikasikan peran mereka agar sama-sama rata maka dapat terjadinya kepuasan dalam pernikahan mereka. Hal ini sependapat dari penelitian sebelumnya (Fowers \& Olson, 1993) menjelaskan bila tidak ada keseimbangan peran pada tempat kerja dan rumah tangga, maka dapat berdampak negatif pada keutuhan dalam keluarga dan kompenen penting dalam rumah tangga seperti kebahagiaan, dan perkembangan suatu keluarga. Hal ini diperkuat oleh Penelitian Ayub \& Shahid (2012) yang mengatakan istri yang 
mendapatkan bantuan dalam mengurus pekerjaan rumah dari suami mereka, istri mengalami tingkat kepuasan pernikahan dan kesejahteraan psikologis yang lebih tinggi tergantung seberapa banyak suami membantu pekerjaan istri di rumah.

Pada tingkat pendidikan suami dan istri terdapat berbagai tingkatan pendidikan dari D3 hingga S2. Dari beberapa latar belakang pendidikan dapat diketahui sebagian besar suami istri yang memiliki komunikasi interpersonal dan kepuasan pernikahan dengan kategori tinggi pada pendidikan D4/S1. Pada penelitian sebelumnya, menjelaskan bahwa tingkat pendidikan yang lebih rendah memiliki kemungkinan yang lebih tinggi pada ketidakpuasan pernikahan dan perceraian (Madanian, \& Syed, 2013). Sedangkan dari sudut pandang suami pasangan yang memiliki tingkat pendidikan yang tinggi cenderung dapat mengekspresikan secara bebas dan cenderung lebih tegas (Ayub \& Shahid, 2012). Menurut (Tokgoz dalam Ayub \& Shahid, 2012) menjelaskan bahwa pasangan yang memiliki gelar sarjana memiliki kepuasan pernikahan yang tinggi daripada pasangan mereka dengan gelar sekolah menengah atas. Sehingga menunjukkan tingkat pendidikan seseorang sangat penting dalam hubungan pernikahan seseorang.

Temuan lain dalam penelitian ini adalah jumlah anak mempengaruhi komunikasi interpersonal maupun kepuasan pernikahan suami dan istri. Semakin banyak jumlah anak pada sepasang suami istri yang berkarier semakin rendah tingkat komunikasi interpersonal dan kepuasan pernikahan mereka. Hal ini dikarenakan intensitas dalam hal berkomunikasi antar pasangan semakin sedikit karena suami maupun istri akan lebih berfokus dalam merawat dan membesarkan anak. Hal ini konsisten dari penelitian sebelumnya Madanian dan Syed (2013) yaitu adanya hubungan negatif antara jumlah anak dengan kepuasan pernikahan pada Imigran Iran yang sudah menikah. Adapun pendapat istri yang menjelaskan bahwa hubungan yang dijalani bersama dengan suami ketika memiliki anak secara emosional berkurang, karena sang suami lebih banyak menghabiskan waktu bersama dengan anak mereka (Benokratis dalam Mardiyan, \& Erin, 2016). Sedangkan Papalia dkk (dalam Mardiyan, \& Erin, 2016) Menemukan bahwa sepasang suami istri yang belum memiliki anak memiliki kepuasan pernikahan lebih tinggi daripada pasangan yang memiliki anak, dan semakin banyak jumlah anak yang dimiliki, semakin tinggi ketidakpuasan dalam pernikahannya.

Pada penelitian ini menunjukan bahwa sumbangan dari komunikasi interpersonal terhadap kepuasan pernikahan pada suami berkarier sebesar $62,5 \%$ dan sisanya yaitu 37,5\% dipengaruhi oleh faktor lain. Sedangkan komunikasi interpersonal terhadap kepuasan pernikahan pada istri berkarier sebesar $49 \%$ dan sisanya $51 \%$ dipengaruhi oleh faktor lain. Maka di dalam pernikahan komunikasi interpersonal memegang peranan penting dalam kepuasan pernikahan seseorang. Kepuasan dalam pernikahan akan membuat pernikahan bertahan lama dan dapat mengurangi kemungkinan terjadinya perceraian (Lavenson et al., dalam Muslimah, 2014).

Selain komunikasi interpersonal mempengaruhi kepuasan pernikahan adapun faktor-faktor lain yang mempengaruhi kepuasan pernikahan. Ziee et al., (2014) mendapatkan hasil yang dilakukan kepada 140 wanita yang sudah menikah dan bekerja di bidang pendidikan dan medis bahwa terdapat hubungan yang signifikan antara kepuasan seksual dan kepuasan pernikahan. Temuan lain menunjukkan 
kepuasan pernikahan secara signifikan berhubungan dengan tingkat pendidikan. Aman et al., (2019) mendapati faktor lain yaitu agama. Mereka mendapati hasil bahwa adanya kecenderungan yang signifikan dalam keagamaan, komponen komitmen keagamaan, dan praktik keagamaan terhadap kepuasan pernikahan pada pasangan Pakistan. Penelitian ini menjelaskan pasangan yang beragama mendapati kehidupan pernikahannya lebih bahagia dan lebih stabil dari pasangan lainnya.

Adigeb dan Mbua (2015) mendapati faktor lain yaitu depresi, kasih sayang dan aktivitas seksual secara signifikan berhubungan dengan kepuasan pernikahan pada Pegawai Negeri. Menjelaskan depresi sebagai faktor psikologis yang mempengaruhi cinta, kasih, dan aktivitas seks pasangan, dalam banyak kasus dapat mengakibatkan ketidakpuasan pernikahan diantara pasangan yang menciptakan masalah dan ketidakharmonisan dalam rumah yang tidak terhitung jumlahnya. Selain itu Herawati dan Sharifah (2017) menemukan kebersyukuran dan pemaaf berhubungan signifikan terhadap kepuasan pernikahan. kebersyukuran dan pemaaf adalah aspek penting dalam memberikan keterlibatan pada kepuasan pernikahan terhadap individu yang sudah menikah dan bekerja. Penelitian ini menjelaskan ketika kebersyukuran diimbangi dengan pemaaf maka dapat menghasilkan energi positif yang dapat mengurangi hambatan, kesulitan menghadapi masalah dalam pekerjaan. Individu yang pemaaf mempengaruhi kesehatan mental dan menjaga kualitas hubungan antar pasangan.

Penelitian ini belum mengakomodasi lama pernikahan dan jumlah pernikahan yang telah dilakukan individu pada kriteria subjek penelitian. Hal ini sangat penting mengingat lama pernikahan dan jumlah pernikahan yang telah dilakukan mempengaruhi kepuasan. Selanjutnya pada saat proses penyebaran kuesioner, peneliti dibantu oleh teman - teman untuk mempersingkat waktu tetapi mengakibatkan peneliti tidak dapat mendampingi satu persatu subjek dalam pengisian kuesioner. Sehingga dapat memunculkan bias dalam pengisian kuesioner, selain itu kriteria subjek pada penelitian ini adalah pasangan suami istri yang berkarier tetapi pada saat penyebaran kuesioner berlangsung mendapati suami atau istrinya saja sehingga peneliti memberikan kuesioner untuk diisi kepada subjek yang sedang berada di rumah dan menitipkan kepada pasangannya untuk mengisi kuesioner tersebut ketika nantinya telah berada di rumah.

\section{SIMPULAN DAN IMPLIKASI}

Berdasarkan hasil penelitian dapat disimpulkan bahwa hubungan positif dan signifikan antara komunikasi interpersonal dengan kepuasan pernikahan pada suami maupun istri yang berkarier. Semakin efektif komunikasi interpersonal maka semakin tinggi tingkat kepuasan pernikahan suami maupun istri. Sebaliknya semakin tidak efektif komunikasi interpersonal maka semakin rendah tingkat kepuasan pernikahan suami maupun istri.

Implikasi dari penelitian ini yaitu mendorong suami dan istri yang berkarier untuk meningkatkan komunikasi interpersonal agar memperoleh kepuasan pernikahan sehingga dapat mempertahankan pernikahan dan dapat menjauhkan dari perceraian. Bagi peneliti selanjutnya diharapkan meneliti dari variabel lain untuk mengukur kepuasan pernikahan dan menambahkan lama pernikahan dan jumlah 
pernikahan yang telah dilakukan individu pada kriteria subjek dikarenakan hal ini sangat penting. Serta penelitian selanjutnya diharapkan mendampingi subjek dari kedua pasangan sehingga mengurangi kecurangan atau eror dalam pengisian kuesioner.

\section{REFERENSI}

Adigeb, A. P., \& Anake, P. M. (2015). The Influence Of Psychosocial Factors On Marital Satisfaction Among Public Servants In Cross River State. Global Journal Of Human-Social Science, 15(8), 12-19. https://globaljournals.org/GJHSS Volume15/2-The-Influence-ofPsychosocial-Factors.pdf

Ali, F. (2017, Mei 05). Pekerjaan Masih Didominasi Laki-Laki. Dari https://bisnis.tempo.co/read/872608/bps-pekerja-masih-didominasi-laki-laki diakses pada tanggal 05 Desember 2018.

Aman, J., Jaffar, A., Mohammad, N., \& Shaher, B. (2019). The Relationship Of Religiosity And Marital Satisfaction: The Role Of Religious Commitment And Practices On Marital Satisfaction Among Pakistani Respondents. Behavioral Sciences, 9(3), 30. DOI: $10.3390 / \mathrm{bs} 9030030$

Arikunto, S. (2010). Prosedur Penelitian Suatu Pendekatan Praktik. Jakarta: Rikena Cipta.

Askari, M., Sidek, N., Siti, H., \& Maznah, B. (2012). Comparison The Effects Of Communication And Conflict Resolution Skills Training On Marital Satisfaction. International Journal of Psychological Studies, 4(1), 182-195. DOI:10.5539/Ijps.V4n1p182

Atta, M., Adnan, A., Sultan, S., \& Sabira, S. (2013). Role Of Trust In Marital Satisfaction Among Single And Dual-Career Couples. International Journal of Research Studies in Psychology, 2, 53-62. DOI: 10.5861/ijrsp.2013.339

Ayub, N. (2010). Development Of Marital Satisfaction Scale. Pakistan Journal of Clinical Psyhology. 9, 19-34.

https://www.researchgate.net/publication/231026047 DEVELOPMENT OF MARITAL S ATISFACTION SCALE

Ayub, N., \& Shahid, I. (2012). The Factors Predicting Marital Satisfaction: A Gender Difference In Pakistan. The International Journal of Interdisciplinary Social Science, 6(7), 63-73. DOI: 10.18848/1833-1882/CGP/v06i07/52112.

Azwar, S. (2013). Metode Penelitian. Yogyakarta: Pustaka Pelajar.

Brandbury, T., Frank, D. F., \& Steven. R. H. B. (2000). Research On The Natue And Determinants Of Marital Satisfaction: A Decade In Review. Journal Of Mariage And The Family, 62(4), 964-980. DOI: 10.1111/j.1741-3737.2000.00964.x

Brockwood, K. J. (2007). Marital Satisfaction And The Work-Family Interface: An Overview, A Sloan Work And Family Encyclopedia Entry. Chestnut hill. MA: Boston College.

Corey, G. (2005). Teori Dan Praktek Dari Konseling Dan Psikoterapi. Jakarta : ERESCO.

Devito, J. A. (1997). Komunikasi Antarmanusia, Edisi 5. (Terj. Maulana, Agus). Jakarta: Professional Book.

Fowers, B. J., \& David, H. O. (1993). ENRICH Marital Satisfaction Scale:A Brier Research And Clinical Tool. Journal of Family Psycholgy, 7 (2), 176-185 http://dx.doi.org/10.1037/0893$\underline{3200.7 .2 .176}$

Handayani, A. (2016). Kepuasan Perkawinan Pada Wanita Menikah Antara Wanita Karier Dan Ibu Rumah Tangga. 155-149. digilib.mercubuana.ac.id/manager/t!@file artikel.../Isi Artikel 221215543210.pdf diakses pada tanggal 10 Juli 2019. 
Hayati, L. R. (2017). Rentang Dasawarsa: Kajian Kepuasan Perkawinan. Skripsi. Fakultas Psikologi. Universitas Muhammadiyah Surakarta. Surakarta. https://core.ac.uk/download/pdf/148617743.pdf diakses pada tanggal 10 Juli 2019.

Herawati, I., \& Syarifah, F. (2017). Kepuasan Perkawinan Ditinjau Dari Kebersyukuran Dan Pemaafan Pada Pasangan Bekerja. Mediapsi, 3(2), 10-21. https://mediapsi.ub.ac.id/index.php/mediapsi/article/view/60/64 diakses pada tanggal 17 Desember 2018

Holman, T. B. (2001). Premarital Prediction Of Marital Quality Or Breakup: Research, Theory, And Practice. New York: Kluwer Academic/Plenum.

Hou, Y., Feng, J., \& Xinrui, W. (2018). Marital Commitment, Communication And Marital Satisfaction: An Analysis Based On Actor-Partner Interdependence Model. International Journal of Psychology, 54(3), 369-376. http://doi.org/ 10.1002/ijop.12473

Istiqomah, I. M., \& Mukhlis. (2015). Hubungan Antara Religiusitas Dengan Kepuasan Pernikahan. Jurnal Psikologi, $11 \quad$ (2). http://ejournal.uinsuska.ac.id/index.php/psikologi/article/view/1396/1210 diakses pada tanggal 20 Desember 2018

Vazhappilly, J. J., \& Marc, E. S. R. (2016). Couples' Communication As A Predictor Of Marital Satisfaction Among Selected Filipino Couples. National Academy of Psychology, 61(4), 301306. https://doi.org/10.1007/s12646-016-0375-5

Joybari, A. A. K., Mahnaz, A. A. D., \& Samira, H. P. (2016). The Effet Of Marital Satisfation In Mothers On Anxiety Of Adolescent Girls. Worl Scientific New, 54, 87-97. http://psjd.icm.edu.pl/psjd/element/bwmeta1.element.psjd-3af7075d-ffde-47bc-9625aff17bf5d4d6

Carroll, S. J., Jeffrey. E. H., Jeremy, B. Y., Jeffry, H. L., \& Jonathan, G. S. Couple Communication As A Mediator Between Work-Family Conflict And Marital Satisfaction. Contemporary Family Therapy, 35 (3), 530-545. DOI: 10.1007/s10591-013-9237-7

Kalliath, P., Thomas, K., \& Varsha, S. (2011). When Work Intersects Family: A Qualitative Exploration Of The Experiences Of Dual Earner Couples In India. South Asian Journal of $\begin{array}{llll}\text { Management, } & 18 & \text { 37-59. }\end{array}$ https://www.researchgate.net/publication/229580995 When Work Intersects Family A Qualitative_Exploration_of the_Experiences_of_Dual_Earner_Couples_in_India

Lavner, J. A., Benjamin, R. K., \& Thomas, N. B. (2016). Does Couples' Communication Predict Marital Satisfaction, Or Does Marital Satisfaction Predict Communication?. National Institutes of Health, 78(3), 680-694. doi: 10.1111/jomf.12301

Lavner, J,. A., Karney, B. R., \& Brandbury, T. N. (2013). Newlyweds Optimistic Forecasts Of Their Marrige For Better Or For Worse?. Journal of Family Psyhology. 27 (4), 531-40. Doi 10.1037/a0033423.

Madanian, L, \& Syed, M. S. S. M. (2013). Marital Satisfaction And Demographic Traits In An Emigrant Sample: Rasch Analysis. Social and Behavioral Sciences, 107, 96-103. https://doi.org/10.1016/j.sbspro.2013.12.404

Manalu, A., Rosyadi, \& Saidin, N. (2014). Faktor-Faktor Yang Mempengaruhi Wanita Bekerja Sebagai Buruh Harian Lepas (BHL) Di PT. Inti Indosawit Subur Muara Bulian Kecamatan Marosebo Ilir Kabupaten Batang Hari. Sosio Ekonomi Bisnis, 17 (2). https://doi.org/10.22437/jiseb.v17i2.2807

Mardiyan, R., \& Erin, R. K. (2016). Kepuasan Pernikahan Pada Pasangan Yang Belum Memiliki Keturunan. Jurnal Empati, 558-565. https://ejournal3.undip.ac.id/index.php/empati/article/view/15406 diakses pada 16 juli 2019 
Maskud, D. (2015). Pola Komunikasi Pasca Perselingkuhan (Perspektif Psikologis Dan Komunikasi Islam). Jurnal Ilmu Dakwah \& Pengembangan Masyarakat, 13 (1). http://ejournal.iain-jember.ac.id/index.php/alhikmah/article/view/382 diakses pada 16 juli 2019

Meliani, F., Euis, S., \& Dian, K. (2014). Faktor Demografi, Konflik Kerja-Keluarga, Dan Kepuasan Pernikahan Istri Bekerja. Jurnal Ilmu Keluarga \& konsultan, 7(3), 133-142. https://journal.ipb.ac.id/index.php/jikk/article/viewFile/10006/7825 diakses pada 16 juli 2019

Mulyana, D. (2000). Ilmu Komunikasi: Suatu Pengantar. Bandung: PT. Remaja Rosdakarya.

Muslimah. A. I. (2014). Kepuasan Pernikahan Ditinjau Dari Keterampilan Komunikasi $\begin{array}{llll}\text { Interpersonal. Surnal Soul. } & \text { Vol.7 }\end{array}$ http://jurnal.unismabekasi.ac.id/index.php/soul/article/view/473 diakses pada 16 juli 2019

Sari, A. N., \& Nailul, F. (2016). Hubungan Antara Empati Dengan Kepuasan Pernikahan Pada Suami Yang Memiliki Istri Bekerja. Jurnal Empati, 5(4), 667-672. https://ejournal3.undip.ac.id/index.php/empati/article/view/15432 diakses pada $16 \mathrm{Juli}$ 2019

Sari, N., Rinaldi, \& Yuninda, T. N. (2018). Hubungan Self Disclosure Dengan Kepuasan Pernikahan Pada Dewasa Awal Di Kota Bukit Tinggi. Jurnal Riset Aktual Psikologi, 9(1). ejournal.unp.ac.id/index.php/psikologi/article/view/10380 diakses pada 10 Juli 2019.

Nurmaya, Y. (2016). Hubungan Antara Komunikasi Efektif Dan Kepuasan Pernikahan Pada Istri Suku Jawa. Skripsi. Semarang: Universitas katolik Soegijipranata. https://repository.usd.ac.id/6733/1/109114158.pdf diakses pada 10 Juli 2019.

Ochsner, T. J. (2012). The Impact Of Dual-Career Marriage On Role Conflict And Marital Satisfaction. Communication Studies Undergraduate Publications, Presentations and Projects. https://pilotscholars.up.edu/cgi/viewcontent.cgi?article=1073\&context=cst_studpubs

Paputungan, F. (2012). Kepuasan Pernikahan Suami Yang Memiliki Istri Berkarir, 1-19. http://psikologi.ub.ac.id/wp-content/uploads/2013/10/IURNAL5.pdf. Diakses pada tanggal 9 Juli 2019.

Paramita, N. K. P., \& Luh, M. K. S. S. (2018). Peran Komunikasi Interpersonal Dan Ekspresi Emosi Terhadap Kepuasan Perkawinan Pada Perempuan Di Usia Dewasa Madya. Jurnal Psikologi Udayana, 5(2), 253. https://ojs.unud.ac.id/index.php/psikologi/article/view/40396 diakses pada tangga $10 \mathrm{Juli}$ 2019.

Patriana, E. (2014). Komunikasi Interpersonal Yang Berlangsung Antara Pembimbing Kemasyarakatan Dan Keluarga Anak Pelaku Pidana Di Bapas Surakarta. Journal of Rural and Development, 5 (2). https://eprints.uns.ac.id/id/eprint/21245 Diakses pada tanggal 9 Juli 2019.

Puspitawati, H. (2012). Gender Dan Keluarga: Konsep Dan Realita Di Indonesia. Bogor: PT IPB Press.

Radar Malang. (2018, Agustus 25). Waduh Tkw Kabupaten Malang Sumbang 356 Angka Cerai. https://radarmalang.id/waduh-tkw-kabupaten-malang-sumbang-356-angka-cerai/ Diakses pada 07 november 2018

Rahma, N. S. (2016). Perbedaan Kepuasan Pernikahan Suami Ditinjau Dari Status Istri. Skripsi. Malang: Universitas Muhammadiyah Malang.

Robinson, L. C., \& Priscilla, W. B. (1993). Marital Strengths In Endurung Marriages. Journal of Family Relations, 42 (1), 38-45. DOI: 10.2307/584919

Sugiono. (2014). Metode Penelitian Kuantitatif, Kualitatif, Dan RED. Bandung: Alfabeta.

Sultana, N., Ayesha, T., \& Abu, A. (2014). Dual-Career Couples In Bangladesh: Exploring The Challenges. Canadian Journal of Family and Younth 6 (1) 29-57. DOI: https://doi.org/10.29173/cjfy21483 


\section{Cognicia}

http://ejournal.umm.ac.id/index.php/cognicia

Taneira, G. P. (2019). Hubungan Antara Kepercayaan Terhadap Pasangan Dan Kepuasan Perkawinan Pada Istri Tentara Batalyon X. Skripsi. Jurusan Psikologi. Univesitas Sanata Dharma. Yogyakarta. https://repository.usd.ac.id/33569/ diakses pada tanggal 10 Juli 2019

Thomas, S., Kay, A., \& Priscilla, W. (1984). Determinants Of Marital Quality In Dual-Career Couples. Family Relations, 33(4), 513-521. DOI: 10.2307/583829

Wardhani, B. S. R. (2015). Perbedaan Kepuasan Pernikahan Pada Wanita Bekerja Dan Tidak Bekerja. Skripsi. Jurusan Psikologi. Universitas Kristen Satya Wacana. Salatiga.

Ziaee, T. et al. (2014). The Relationship Between Marital And Sexual Satisfaction Among Married Woman Employees At Golestan University Of Medical Sciences, Iran. Iran J Psychiatry Behav Sci, 8 (2) 44-51. https://www.ncbi.nlm.nih.gov/pubmed/25053956 